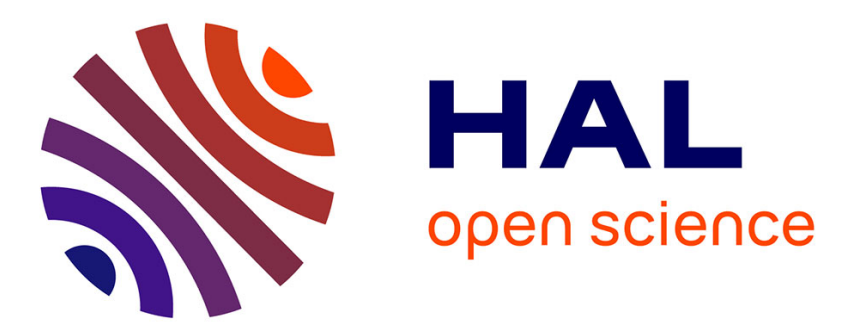

\title{
DECAY AND FORMATION RATES OF Xe* (3P1, 3P2) AND Xe2* [MATH] FOR Ar-Xe HIGH PRESSURE LASER MIXTURES
}

N. Sazhina, N. Ustinovsky, I. Kholin

\section{- To cite this version:}

N. Sazhina, N. Ustinovsky, I. Kholin. DECAY AND FORMATION RATES OF Xe* (3P1, 3P2) AND Xe2* [MATH] FOR Ar-Xe HIGH PRESSURE LASER MIXTURES. Journal de Physique IV Proceedings, 1991, 01 (C7), pp.C7-593-C7-593. 10.1051/jp4:19917160 . jpa-00250837

\section{HAL Id: jpa-00250837 https://hal.science/jpa-00250837}

Submitted on 1 Jan 1991

HAL is a multi-disciplinary open access archive for the deposit and dissemination of scientific research documents, whether they are published or not. The documents may come from teaching and research institutions in France or abroad, or from public or private research centers.
L'archive ouverte pluridisciplinaire HAL, est destinée au dépôt et à la diffusion de documents scientifiques de niveau recherche, publiés ou non, émanant des établissements d'enseignement et de recherche français ou étrangers, des laboratoires publics ou privés. 


\section{DECAY AND FORMATION RATES OF Xe* $\left({ }^{3} \mathbf{P}_{1},{ }^{3} \mathbf{P}_{2}\right)$ AND Xe $\mathrm{Xe}_{2}^{*}\left({ }^{3} \sum_{u}^{+}\right)$FOR Ar-Xe HIGH PRESSURE LASER MIXTURES}

N.N. SAZHINA, N.N. USTINOVSKY and I.V. KHOLIN

P.N. Lebedev Physical Institute, Leninsky Prospect 53, Moscow 117924, USSR

We used time resolved absorption measurements to investigate the decay and formation rates of the $\mathrm{Xe}^{*}\left({ }^{3} \mathrm{P}, 1,2\right), \mathrm{Xe}_{2}^{*}\left({ }^{3} \Sigma_{u}^{+}\right)$ states in Ar-Xe high pressure laser mixtures $(0,5 \div 3 \mathrm{~atm})$ with Iow Xe eraotions $10^{-2} \div 10^{-5}$. As an excitation source electron beam with $\Pi$-shaped pulses was used. From analyses of the dependence of the afterglow decay rates upon Xe and Ar partial concentrations we have obtained the effective rate oonstants for two- and three-body quenching collisions $\mathrm{Xe}^{*}\left({ }^{3} \mathrm{P}, 2\right)$ with neutral particles. Two-body collisional deexitation of the $\mathrm{Xe}^{*}\left({ }^{3} \mathrm{P}_{1}\right)$ and $\mathrm{Xe}^{*}\left({ }^{3} \mathrm{P}_{2}\right)$ by $\mathrm{Ar}$ is observed with the rate constants $(9 \pm 3)$. $10^{-15}$ and $(2,5 \pm 0,8) \cdot 10^{-15} \mathrm{~cm}^{3} \mathrm{~s}^{-1}$. For the three-body reactions

$$
\begin{aligned}
& \mathrm{Xe}^{*}\left({ }^{3} \mathrm{P}_{1}\right)+\mathrm{Xe}+\mathrm{Ar} \rightarrow \mathrm{Xe}_{2}^{*}\left({ }^{1} \Sigma_{u}^{+}\right)+\mathrm{Ar} \\
& \mathrm{Xe}^{*}\left({ }^{3} \mathrm{P}_{2}\right)+\mathrm{Xe}+\mathrm{Ar} \rightarrow \mathrm{Xe}_{2}^{*}\left({ }^{3} \Sigma_{u}^{+}\right)+\mathrm{Ar}
\end{aligned}
$$

we have obtained rate constants $(2,8 \pm 0,9) \cdot 10^{-32}$ and $(1,8 \pm 0,6)$. $10^{-32} \mathrm{~cm}^{6} \mathrm{~s}^{-1}$. Most authors $/ 1 /$ suppose that at the Iow $\mathrm{Xe}$ concentration seoond order reaction

$$
\mathrm{Xe} e^{*}+2 \mathrm{Ar} \rightarrow \mathrm{ArXe} e^{*}+\mathrm{Ar}
$$

would be the main quenching process. In our experiments, performed in the wide range of experimental conditions, we haven' $t$ noticed any decay rate components, proportional to the $[\mathrm{Ar}]^{2}$. Also it is shown that the reaction discussed combined with the reverse one

$$
\operatorname{ArXe} e^{*}+\operatorname{Ar} \rightarrow X e^{*}+2 \mathrm{Ar}
$$

the role of which is high enough due to the small binding energy of ArXe*, can produce the definite part to the components, which are linear against [Ar].

1."Excimer Lasers",C.K.Rhodes, Ed. Berlin:Springer-Verlag,1979. 